\title{
MENINGKATKAN KEMAMPUAN KOGNITIF PENDIDIKAN PANCASILA DAN KEWARGANEGARAAN (PPKN) MATERI PERUMUSAN DAN PENETAPAN PANCASILA SEBAGAI DASAR NEGARA MELALUI MODEL PEMBELAJARAN THINK PAIR SHARE
}

Improving Cognitive Capabilities Pancasila And Citizenship Education (Ppkn) Materials For The Formulation And Determination Of Pancasila As The State Basic Through The Think Pair Share Learning Model Oleh : Titussiana

Email: thitussiana@gmail.com

\begin{abstract}
ABSTRAK
Berdasarkan hasil penelitian ditemukan beberapa faktor yang menjadi penyebab rendahnya kemampuan kognitif siswa pada pembelajaran Pendidikan Pancasila dan Kewarganegaraan (PPKn) materi perumusan dan penetapan Pancasila sebagai dasar negara. Faktor pertama, siswa kurang dilibatkan secara aktif dalam kegiatan pembelajaran. Siswa lebih berperan sebagai penerima informasi pasif, bukan sebagai subjek yang melakukan aktivitas belajar, sehingga perhatian siswa sering teralih pada hal-hal lain di luar materi pelajaran walaupun penyediaan fasilitas kegiatan pembelajaran sudah baik.

Tujuan dalam penelitian ini, antara lain: Untuk mengetahui pelaksanaan model pembelajaran think pair share pada siswa. Untuk mengetahui kemampuan kognitif Pendidikan Pancasila dan Kewarganegaraan (PPKn) materi perumusan dan penetapan Pancasila sebagai dasar negara. Untuk mengetahui pelaksanaan model pembelajaran think pair share dapat meningkatkan kemampuan kognitif Pendidikan Pancasila dan Kewarganegaraan (PPKn) materi perumusan dan penetapan Pancasila sebagai dasar negara.

Berdasarkan hasil penelitian, dapat diketahui kemampuan kognitif siswa dengan melaksanakan model pembelajaran think pair share mulai siklus I sampai dengan siklus II terus mengalami peningkatan yang cukup signifikan, yaitu dari kenaikan nilai rata-rata kemampuan kognitif sebesar 76,92 kemudian mengalami peningkatan pada siklus II adalah sebesar 81,48. Sehingga terdapat peningkatan nilai kemampuan kognitif sebesar 4,56. Dengan demikian kemampuan kognitif Pendidikan Pancasila dan Kewarganegaraan (PPKn) materi perumusan dan penetapan Pancasila sebagai dasar negara yang diperoleh siswa mengalami peningkatan yang cukup signifikan setelah dilaksanakan model pembelajaran think pair share.
\end{abstract}

Kata Kunci: Think Pair Share, Kemampuan Kognitif PPKn, Dasar Negara.

\section{ABSTRACT}

Based on the results of the study, it was found that several factors were the cause of the low cognitive abilities of students in learning Pancasila and Citizenship Education (PPKn) the material for the formulation and stipulation of Pancasila as the basis of the state. The first factor is that students are not actively involved in learning activities. Students act more as passive recipients of information, not as subjects who carry out learning activities, so students' attention is often diverted to other things outside the subject matter even though the provision of learning activity facilities is good.

The objectives of this study, among others: To determine the implementation of the think pair share learning model for students. To determine the cognitive abilities of Pancasila and Citizenship Education (PPKn) the material for the formulation and stipulation of Pancasila as the basis of the state. To find out the implementation of the think pair share 
learning model can improve the cognitive ability of Pancasila and Citizenship Education (PPKn) the material for the formulation and stipulation of Pancasila as the basis of the state.

Based on the results of the study, it can be seen that students' cognitive abilities by implementing the think pair share learning model from cycle I to cycle II continue to experience a significant increase, namely from an increase in the average value of cognitive abilities of 76.92 then an increase in cycle II is of 81.48. So there is an increase in the value of cognitive abilities of 4.56. Thus, the cognitive ability of Pancasila and Citizenship Education (PPKn) material for the formulation and determination of Pancasila as the basis of the state obtained by students has increased significantly after the think pair share learning model was implemented.

Keywords: Religious Values, Poetry, Sociology of Literature.

\section{PENDAHULUAN}

Berdasarkan hasil penelitian ditemukan beberapa faktor yang menjadi penyebab rendahnya kemampuan kognitif siswa Kelas VII-B SMP Muhammadiyah Buntok pada pembelajaran Pendidikan Pancasila dan Kewarganegaraan (PPKn) materi perumusan dan penetapan Pancasila sebagai dasar negara. Faktor pertama, siswa kurang dilibatkan secara aktif dalam kegiatan pembelajaran. Siswa lebih berperan sebagai penerima informasi pasif, bukan sebagai subjek yang melakukan aktivitas belajar, sehingga perhatian siswa sering teralih pada hal-hal lain di luar materi pelajaran walaupun penyediaan fasilitas kegiatan pembelajaran sudah baik misalnya laboratorium, perpustakaan, komputer, media pembelajaran audiovisual dan lain sebagainya. Kelengkapan fasilitas ini belum dapat meningkatkan motivasi belajar siswa. Faktor kedua, penggunaan metode atau model pembelajaran yang digunakan belum mampu meningkatkan kemampuan kognitif siswa terhadap materi yang disajikan.

Guru sebagai pengajar perlu mengatasi duduk perkara tadi galat satunya menggunakan mencoba strategi pembelajaran yang lebih menarik bagi siswa agar dapat membangkitkan motivasi belajar dan kemampuan kognitif peserta didik dalam pembelajaran. Pemilihan pendekatan pembelajaran dibutuhkan dapat membantu mempertinggi motivasi belajar peserta didik dalam proses pembelajaran.
Metode yang bisa digunakan sebagai alternatif ialah metode pembelajaran kooperatif Think Pair Share.

Think Pair Share memberikan kepada para siswa ketika buat berpikir dan merespon serta saling bantu satu sama lain. Think-Pair-Share memberi peserta didik kesempatan buat bekerja sendiri dan bekerja sama menggunakan orang lain. dengan metode klasikal yang memungkinkan hanya satu peserta didik maju dan menunjukkan hasilnya buat semua kelas, akan tetapi pembelajaran ini memberi kesempatan sedikitnya delapan kali lebih banyak pada siswa buat dikenali serta memberikan partisipasi mereka kepada orang lain (Nurhadi, 2004: 66).

Guru memainkan lebih banyak peran koordinasi dan berkontribusi jika mereka mau. Guru tidak hanya berdiri di depan kelas, tetapi sering berkeliling untuk melihat lebih dekat proses pembelajaran yang sedang dilakukan siswa, sehingga membantu siswa untuk memecahkan masalah yang dihadapinya. Meskipun guru tidak hadir di depan kelas, kelas tidak ribut, karena semua siswa bekerja berpasangan dalam mengerjakan soal-soal praktikum.

Guru yang berpindah dari meja ke meja juga mendorong siswa yang tidak pernah bertanya karena takut bertanya. Selain itu juga memudahkan guru untuk membantu siswa yang kesulitan memahami cara menyelesaikan soal. Penelitian ini bertujuan untuk mengeksplorasi penerapan contoh 
pembelajaran bersama reflektif, untuk mengetahui kapasitas kognitif Dokumen Pendidikan dan Kewarganegaraan Pancasila (PPKn) untuk membangun dan mengidentifikasi Pancasila sebagai dasar "Negara bagi peserta didik". Think Pair Share merupakan salah satu teknik pembelajaran yang ada pada contoh pembelajaran kooperatif mengikuti sistem pembelajaran kooperatif atau pembelajaran kelompok dengan menggunakan tugastugas terstruktur yang berhubungan dengan pencapaian tujuan pemecahan masalah. Metode ini diawali dengan sikap tanya jawab dan siswa berpikir mandiri, yang diperlukan untuk meningkatkan motivasi belajar agar siswa lebih memperhatikan pelajaran. Kegiatan selanjutnya melibatkan siswa berdiskusi berpasangan.

Pemilihan metode Think Pair Share karena pembelajaran kooperatif ini memberi kesempatan peserta didik buat bekerja sendiri dan bekerja sama menggunakan orang lain serta mengoptimalisasikan partisipasi siswa. sebagai akibatnya diharapkan peserta didik akan lebih terdorong serta termotivasi untuk lebih giat belajar dan mengikuti pembelajaran. siswa dapat saling bertukar info dengan peserta didik lain untuk menuntaskan konflik secara beserta-sama sehingga diharapkan akan menaikkan motivasi belajar peserta didik. Pembelajaran dilakukan dengan metode ceramah, latihan soal, tanya jawab, serta penugasan. Pembelajaran tersebut bersifat menegangkan serta menakutkan sebagian akbar peserta didik. Selama proses pembelajaran siswa lebih poly pasif. kondisi tersebut mengakibatkan siswa tidak memahami materi yang dipelajari.

Pembelajaran dilakukan menggunakan menerapkan metode pembelajaran kooperatif tipe TPS (ThinkPair-Share). peserta didik lebih berperan aktif, guru merangsang peserta didik mengerjakan latihan-latihan soal secara berpasangan dan lalu mengatakan hasilnya kepada grup lain. Proses ini lebih

menyenangkan dan memacu siswa buat mengerjakan soal latihan.

Kemampuan kognitif mengacu pada keterampilan yang berkaitan dengan penguasaan ilmu pengetahuan dan teknologi. Setiap orang memiliki persepsi mengamati atau menyerap suatu objek. Ini berarti bahwa dia mengendalikan sesuatu yang diketahui, dalam arti bahwa persepsi terbentuk di dalam dirinya, dan pengetahuan itu secara sistematis mengatur dirinya sendiri untuk menjadi miliknya. Setiap kali, jika diramalkan, pengetahuannya bisa direproduksi. sedikit banyak benar atau kurang pengetahuan yang sempurna dapat dimiliki dan direproduksi dan ini adalah tingkat kapasitas kognitif seseorang.

Ranah kognitif adalah ranah yang berkaitan dengan tujuan pembelajaran yang berkaitan dengan penggunaan proses mental mulai dari sumber pengetahuan sampai ke jenjang yang lebih tinggi, yaitu penilaian. . Tempat persepsi ini terdiri dari 6 (enam) tingkatan yang diurutkan dari yang paling rendah (pengetahuan) sampai yang paling tinggi (evaluasi). (Hamzah B. Uno, 2006: 35).

Kesempatan peserta didik buat bekerja sendiri dan bekerja sama menggunakan orang lain serta mengoptimalisasikan partisipasi siswa. sebagai akibatnya diharapkan peserta didik akan lebih terdorong serta termotivasi untuk lebih giat belajar dan mengikuti pembelajaran. siswa dapat saling bertukar info dengan peserta didik lain untuk menuntaskan konflik secara beserta-sama sehingga diharapkan akan menaikkan motivasi belajar peserta didik. Pembelajaran dilakukan dengan metode ceramah, latihan soal, tanya jawab, serta penugasan. Pembelajaran tersebut bersifat menegangkan serta menakutkan sebagian akbar peserta didik. Selama proses pembelajaran siswa lebih poly pasif. kondisi tersebut mengakibatkan siswa tidak memahami materi yang dipelajari.

Pembelajaran

menggunakan menerapkan dilakukan metode 
pembelajaran kooperatif tipe TPS (ThinkPair-Share). peserta didik lebih berperan aktif, guru merangsang peserta didik mengerjakan latihan-latihan soal secara berpasangan dan lalu mengatakan hasilnya kepada grup lain. Proses ini lebih menyenangkan dan memacu siswa buat mengerjakan soal latihan.

Kemampuan kognitif mengacu pada keterampilan yang berkaitan dengan penguasaan ilmu pengetahuan dan teknologi. Setiap orang memiliki persepsi mengamati atau menyerap suatu objek. Ini berarti bahwa dia mengendalikan sesuatu yang diketahui, dalam arti bahwa persepsi terbentuk di dalam dirinya, dan pengetahuan itu secara sistematis mengatur dirinya sendiri untuk menjadi miliknya. Setiap kali, jika diramalkan, pengetahuannya bisa direproduksi. sedikit banyak benar atau kurang pengetahuan yang sempurna dapat dimiliki dan direproduksi dan ini adalah tingkat kapasitas kognitif seseorang.

Ranah kognitif adalah ranah yang berkaitan dengan tujuan pembelajaran yang berkaitan dengan penggunaan proses mental mulai dari sumber pengetahuan sampai ke jenjang yang lebih tinggi, yaitu penilaian. . Tempat persepsi ini terdiri dari 6 (enam) tingkatan yang diurutkan dari yang paling rendah (pengetahuan) sampai yang paling tinggi (evaluasi). (Hamzah B. Uno, 2006: 35).

Intinya adalah bahwa kemampuan kognitif adalah hasil belajar. Seperti kita ketahui, efektivitas belajar merupakan rangkaian faktor bawaan dan pengaruh lingkungan (faktor dasar dan faktor didaktis). Faktor utama yang memiliki pengaruh lebih besar pada kemampuan kognitif dapat dibedakan sebagai lingkungan alami dan buatan. Proses belajar mengajar merupakan upaya untuk menciptakan lingkungan yang positif, teratur dan terencana untuk mengembangkan blok bangunan yang sudah dimiliki anak. tingkat kompetensi kognitif yang tercermin dalam hasil belajar yang diukur dengan tes sebagai hasil belajar.

Kecerdasan sangat mempengaruhi kemampuan kognitif seseorang. Dikatakan ada hubungan yang tinggi dan positif antara kecerdasan dengan nilai kemampuan kognitif, semakin tinggi nilai intelektual seseorang maka semakin besar pula kemampuan kognitifnya.

Setiap negara membutuhkan ideologi. Ideologi sangat menentukan bagi kehidupan berbangsa dan bernegara. Hal ini karena ideologi memberikan kejelasan tentang ciri-ciri bangsa, inspirasi, cita-cita, dan motivasi untuk mencapai tujuan negara. Seperti negara lain, negara Indonesia juga memiliki ideologi. Ideologi bangsa Indonesia diambil dari nilai-nilai budaya bangsa. Ideologi negara Indonesia telah diadaptasi dengan menggunakan nilai-nilai dan adat istiadat negara Indonesia. Nilai-nilai tersebut tercantum dalam Pancasila.Setiap bangsa yang merdeka tentu memiliki dasar negara. Indonesia menjadi sebuah negara yang merdeka mempunyai dasar negara yang dianggap dengan Pancasila. Pancasila artinya idelogi negara yang digali asal nilai-nilai luhur kebudayaan serta peradaban bangsa Indonesia sendiri. sang sebab itu, Pancasila pada dalamnya mempunyai nilai-nilai yang mencerminkan khazanah sekaligus karakter bangsa Indonesia yang harus dipahami, dijadikan pedoman, dihayati, serta diamalkan oleh semua masyarakat Indonesia.

Dasar negara artinya pondasi berdirinya sebuah negara. Ibarat sebuah bangunan, tanpa pondasi yang bertenaga tentu tidak akan berdiri dengan kokoh. oleh karena itu, dasar negara menjadi pondasi wajib disusun sekuat mungkin sebelum suatu negara berdiri. Dasar negara merupakan dasar buat mengatur penyelenggaraan ketatanegaraan suatu negara dalam bidang ideologi, politik, ekonomi, sosial budaya, serta Dasar negara artinya pondasi berdirinya sebuah negara. Ibarat sebuah bangunan, tanpa pondasi yang bertenaga tentu tidak akan berdiri 
dengan kokoh. oleh karena itu, dasar negara menjadi pondasi wajib disusun sekuat mungkin sebelum suatu negara berdiri. Dasar negara merupakan dasar buat mengatur penyelenggaraan ketatanegaraan suatu negara dalam bidang ideologi, politik, ekonomi, sosial budaya, serta pertahanan serta keamanan. Dasar negara merupakan falsafah negara yang berkedudukan sebagai asal berasal segala asal hukum. Falsafah negara atau dasar negara menjadi perilaku hidup, etos bagi warga , bangsa, dan negara. Dasar negara yang digunakan di Indonesia merupakan Pancasila.

Dasar negara bisa berupa suatu falsafah yang dapat merangkum atau menyimpulkan kehidupan dan cita-cita bangsa dan negara Indonesia yang merdeka. Dasar negara ialah fondasi atau landasan yang bertenaga serta kokoh serta tahan terhadap segala gangguan, kendala maupun rintangan asal pada juga asal luar, sebagai akibatnya bangunan gedung pada atasnya dapat berdiri menggunakan kokoh serta bertenaga. Bangunan itu artinya negara Republik Indonesia yang ingin mewujudkan suatu masyarakat yang adil dan makmur. Tujuan dirumuskannya Pancasila oleh para pendiri negara ialah menjadi dasar negara Republik Indonesia. Hal ini sesuai apa yang dikatakan oleh Radjiman Widyodiningrat bahwa hakikat Pancasila artinya sebagai dasar negara. Demikian juga Muhammad Yamin, Mr. Soepomo dan Ir. Soekarno pula menyebutkan perlu adanya dasar negara Indonesia yang merdeka yaitu Pancasila. menggunakan demikian, para pelaku sejarah memang berniat merumuskan Pancasila menjadi landasan negara, menjadi falsafah negara serta ideologi negara serta tidak ada niatan lainnya.

Pancasila menjadi dasar negara berarti Pancasila sebagai dasar atau pedoman pada penyelenggaraan negara. andai saja negara ialah sebuah bangunan, maka Pancasila menjadi fondasi yang nantinya akan dijadikan tempat berpijak bangunan-bangunan berikutnya. dengan demikian, Pancasila dijadikan dasar serta tonggak dalam pembuatan segala peraturan perundang-undangan negara serta berbagai peraturan lainnya yang mengatur di aneka macam bidang kehidupan baik politik, ekonomi, sosial, budaya, pendidikan, juga pertahanan serta keamanan. di samping Pancasila sebagai dasar negara, Pancasila juga sebagai cumber hukum yang paling primer bagi segala perundang-undangan yang akan dibuat serta digali. oleh sebab itu, Pancasila pada samping memerankan diri menjadi dasar negara pula memerankan diri sebagai asal tertib hukum bagi Republik Indonesia.

Perumusan Pancasila sebagai dasar negara Republik Indonesia tidak terlepas berasal sejarah usaha bangsa Indonesia buat merebut kemerdekaan. di masa pendudukan Jepang tahun 1942, awalnya bangsa Indonesia menyambut baik kedatangan Jepang. Rupanya kedatangan Jepang tak membarui nasib bangsa ke arah yang lebih baik, bahkan kebalikannya, ternyata lebih kejam daripada pemerintah Hindia Belanda. Maka pada daerah-daerah muncul perlawanan terhadap Jepang di tahun 1943 posisi Jepang semakin genting sebab menghadapi gempuran tentara Sekutu. di samping itu, mereka pula menghadapi perlawanan di setiap wilayah. kondisi semacam ini dimanfaatkan sang bangsa Indonesia buat mendesak Jepang agar bersedia menyampaikan kemerdekaan kepada bangsa Indonesia. desakan tadi ternyata menerima respon asal pemerintah Jepang. pada lepas 7 September 1944 Perdana Menteri Koyso menjanjikan kemerdekaan kelak di kemudian hari. buat meyakinkan bangsa Indonesia terhadap janji tadi, dibentuklah BPUPKI (Badan Penyelidik usaha-perjuangan Persiapan Kemerdekaan Indonesia) atau Dokuritsu Zyunbi Tyoshakai pada 1 September 1945. Anggota BPUPKI ini terdiri asal 60 anggota dari asal Indonesia, 4 anggota keturunan Cina, satu anggota keturunan Belanda dan satu anggota berasal keturunan Arab. 
Jenderal Kumakichi Harada, Komandan Pasukan Jepang untuk Jawa pada tanggal 1 September 1945 mengumumkan pembentukan BPUPKI. Pada tanggal 28 April 1945 diumumkan pengangkatan anggota BPUPKI. Upacara peresmiannya dilaksanakan di Gedung Cuo Sangi In di Pejambon Jakarta (sekarang Gedung Departemen Luar Negeri). Ketua BPUPKI ditunjuk Jepang adalah dr. Rajiman Wedyodiningrat, wakilnya adalah Icibangase (Jepang), dan sebagai sekretarisnya adalah R.P. Soeroso. Jumlah anggota BPUPKI adalah 63 orang yang mewakili hampir seluruh wilayah Indonesia ditambah 7 orang tanpa hak suara.

Menjelang Proklamasi Kemerdekaan Indonesia, istilah Pancasila kembali mencuat ke permukaan. Pada sidang BPUPKI (Badan Penyelidik Usaha-usaha Persiapan Kemerdekaan Indonesia) yang pertama tanggal 1 Juni 1945, Ir. Soekarno dalam pidatonya mengatakan “... namanya bukan Panca Dharma, tetapi saya namakan ini dengan petunjuk seorang teman kita ahli bahasa, namanya Pancasila. Sila artinya asas atau dasar, dan di atas kelima dasar itulah kita mendirikan negara Indonesia, kekal dan abadi." Setelah berakhirnya sidang BPUPKI tersebut dibentuklah Panitia Sembilan yang pada tanggal 22 Juni 1945 berhasil merumuskan "Piagam Jakarta". Pada tanggal 18 Agustus 1945, sehari setelah Indonesia merdeka, PPKI (Panitia Persiapan Kemerdekaan Indonesia) menetapkan rumusan Pancasila sebagai Dasar Negara Republik Indonesia sebagaimana terdapat Pembukaan UUD 1945, alinea IV dengan urutan sebagai berikut:

1. Ketuhanan Yang Maha Esa

2. Kemanusiaan yang adil dan beradab

3. Persatuan Indonesia

4. Kerakyatan yang dipimpin oleh hikmat kebijaksanaan dalam permusyawaratan/ perwakilan

5. Keadilan sosial bagi seluruh rakyat Indonesia

\section{METODE PENELITIAN}

Penelitian tindakan kelas berasal dari istilah Pendidikan Pancasila dan Kewarganegaraan (PPKn) Classroom Action Research, yang dikenal dengan singkatan PTK yaitu penelitian yang dilakukan di kelas oleh guru/peneliti untuk mengetahui yang berarti penelitian yang dilakukan pada sebuah kelas untuk mengetahui akibat tindakan yang diterapkan pada suatu subyek penelitian di kelas tersebut. (Muhammad Afandi, 2011:35). Penelitian tindakan kelas pertama kali diperkenalkan oleh Kurt Lewin pada tahun 1946, yang selanjutnya dikembangkan oleh ahli-ahli lain seperti Stephen Kemmis, Robin Mc Taggart, John Elliot, Dave Ebbutt dan sebagainya. Dengan demikian konsep penelitian tindakan kelas semakin berkembang sesuai dengan perkembangan ilmu pengetahuan dan teknologi, Pemahaman konsep penelitian tindakan banyak para peneliti atau penulis menjelaskan konsep yang memang dibutuhkan dalam pelaksanaannya di dalam proses pembelajaran.

Penelitian tindakan (action research) adalah suatu bentuk penelitian yang dilakukan oleh guru untuk meneliti sendiri praktek pembelajaran yang dilakukan dikelas.dalam penelitian tindakan kelas, guru dan peneliti secara kolaboratif juga dapat melakukan penelitian terhadap proses atau produk pembelajaran secara reflektif di kelas. Penelitian tindakan juga menjembatani kesenjangan antara teori dan praktik pendidikan. Hal ini terjadi karena setelah peneliti kegiatanya sendiri, yakni didalam kelas dengan melibatkan siswanya dengan melalui tindakan-tindakan yang direncanakan.

Penelitian tindakan kelas terdiri atas rangkaian empat kegiatan yang dilakukan dalam siklus berulang. Empat kegiatan utama yang ada pada setiap siklus, yaitu (a) perencanaan, (b) pelaksanaan, (c) pengamatan, dan (d) refleksi. Yang 
diuraikan dalam siklus hanya bagian yang dimodifikasi melalui action reseach, bukan seluruh proses pembelajaran. Modifikasi atau perubahan secara total jarang dilakukan dalam action research yang berskala kelas karena bagaimanapun sistem pendidikan secara umum masih belum berubah.

\section{HASIL PENELITIAN DAN PEMBAHASAN}

\section{Siklus I}

Adapun tindakan siklus pertama, ada beberapa tindakan penting yang dilakukan oleh guru sebagai peneliti supaya model pembelajaran think pair share dapat dilaksanakan secara optimal. Sehingga membawa dampak pada meningkatnya kemampuan kognitif siswa. Sedangkan tindakan-tindakan tersebut adalah sebagai berikut:

1) Memberikan penghargaan

Untuk siswa yang mampu melaksanakan pembelajaran dengan baik, yang ditunjukkan dengan adanya sikap yang satun selama pembelajaran, aktif dalam berdiskusi, mengajukan pertanyaan dan jawaban. Selain itu mendapat nilai ulangan yang baik, maka guru memberikan penghargaan, yang berupa: sanjungan. Hal ini dilakukan dengan harapan supaya siswa tersebut lebih meningkatkan belajarnya dan ditiru oleh teman-temannya.

2) Membentuk kelompok belajar

Dalam rangka meningkatkan kualitas pembelajaran dan kemampuan kognitif siswa, maka kelas dibentuk menjadi beberapa kelompok yang terdiri dari lima siswa. Setiap kelompok diberikan tugas terkait materi pembelajaran yang telah ditentukan oleh guru.

3) Memberikan petunjuk pelaksanaan model pembelajaran think pair share

Berdasarkan hasil pengamatan sebagian siswa masih belum tahu dan Titussiana

SMP Muhammadiyah Buntok kesulitan dalam melaksanakan model pembelajaran think pair share. Karena hal itu dirasa asing dan siswa belum terbiasa. Untuk mengatasinya maka guru memberikan petunjuk pelaksanaannya.

Pada tahap observasi ini langkahlangkah yang dilakukan adalah sebagai berikut:

a. Mengamati perilaku siswa dalam pembelajaran.

b. Memantau diskusi/kerja sama antarsiswa.

c. Mengamati pemahaman masing-masing siswa.

d. Memantau pelaksanaan model pembelajaran think pair share.

Pada siklus tahapan observasi ini, peneliti berusaha mengamati pelaksanaan model pembelajaran think pair share pada pembelajaran Pendidikan Pancasila dan Kewarganegaraan (PPKn) materi perumusan dan penetapan Pancasila sebagai dasar negara. Terdapat beberapa kendala atau masalah yang terjadi. Selain itu, peneliti juga berusaha mengatasi setiap permsalahan yang terjadi pada saat pembelajaran, serta berupaya memperbaikinya untuk siklus selanjutnya. Untuk lebih jelasnya berikut, peneliti sajikan kendala atau masalah dan upaya penyelesaiannya.

1) Diskusi didominasi oleh siswa yang pandai bicara

Dalam kelompok terdapat beberapa siswa, di antara siswa-siswa tersebut tentunya ada siswa yang aktif berbicara dan yang lainnya pasif dalam berbicara. Siswa yang pandai bicara mendominasi dalam pelaksanaan diskusi, sehingga teman-temannya yang lainnya kurang mendapatkan giliran untuk menyampaikan pendapat dan pemikirannya.

Untuk menyelesaikan masalah ini, guru memberikan giliran kepada siswa yang 
lainnya agar aktif mengemukakan pendapat. Selain itu memberikan batasan waktu kepada siswa yang over speaking dalam berdiskusi.

\section{2) Adanya kegaduhan}

Dapat dibayangkan bahwa dalam satu kelas terdapat tiga puluh lima siswa dan hanya dibimbing oleh satu guru, tentunya suasananya akan berbeda dengan siswa yang jumlahnya sedikit. Pada saat berlangsungnya pembelajaran, ternyata masih terdapat siswa yang ramai dan asyik bermain, bercanda dengan temantemannya. Posisi siswa yang ramai ini pada umumnya terletak jauh dari pantauan guru.

Menjadi solusi dalam menyingkapi dilema tadi, tindakan yang dilakukan sang pengajar ialah menyampaikan teguran serta peringatan kepada siswa yang ramai serta menghasilkan gaduh suasana pembelajaran. Berdasarkan yang akan terjadi pengamatan ternyata masih poly siswa yang belum aktif buat melaksanakan model pembelajaran think pair share. Selain itu, masih banyak peserta didik yang tidak berani bertanya juga menjawab pertanyaan yang diberikan. sehingga perlu adanya penguasaan konsep, perilaku ilmiah dan keterampilan ilmiah wajib seimbang buat mengaktifkan siswa. oleh sebab itu, peneliti memutuskan untuk melanjutkan di siklus kedua, agar yang akan terjadi yang didapat semakin baik.

Sesuai yang akan terjadi observasi perihal kemampuan kognitif belajar Pendidikan Pancasila serta Kewarganegaraan (PPKn) materi perumusan serta penetapan Pancasila menjadi dasar negara melalui aplikasi contoh pembelajaran think pair share pada siklus I. berdasarkan akibat observasi di atas, bisa diketahui bahwa nilai homogenhomogen kemampuan kognitif berasal 25 Titussiana siswa artinya sebanyak 76,92. dari data jua dapat diketahui bahwa jumlah peserta didik yang mendapatkan nilai KKM (kriteria ketuntasan minimal) sebanyak 18 peserta didik atau $72 \%$.

Sedangkan yang mendapatkan nilai di bawah nilai KKM sebanyak 7 siswa atau $28 \%$. sesuai akibat pengamatan ternyata masih poly siswa yang belum aktif buat melakukan belajar. Masih terdapat siswa yang kesulitan pada tahu materi pembelajaran. Sebagian siswa ada yang membuat malu mengutarakan pendapatnya ketika berdiskusi. Selain itu, masih poly siswa yang tak berani bertanya juga menjawab pertanyaan yang diberikan. sehingga perlu adanya dominasi konsep, perilaku ilmiah dan keterampilan ilmiah wajib seimbang buat mengaktifkan siswa dari akibat pelaksanaan contoh pembelajaran think pair share, ternyata belum dapat dilaksanakan secara optimal. Hal ini terbukti dari hasil nilai kemampuan kognitif peserta didik terkait materi perumusan dan penetapan Pancasila menjadi dasar negara belum sinkron menggunakan asa serta ketuntasan belajar tak mencapai $75 \%$. Oleh sebab itu, peneliti menetapkan buat melanjutkan siklus penelitian ke siklus berikutnya, yaitu siklus II.

\section{Siklus II}

Berdasarkan hasil observasi siklus kedua ini, peneliti mengamati pelaksanaan model pembelajaran think pair share pada pembelajaran Pendidikan Pancasila dan Kewarganegaraan (PPKn) materi perumusan dan penetapan Pancasila sebagai dasar negara. Terdapat beberapa kendala atau masalah yang terjadi. Selain itu, peneliti juga berusaha mengatasi setiap permasalahan yang terjadi pada saat pembelajaran, serta berupaya memperbaikinya untuk siklus selanjutnya. Masalah atau kendala pada siklus kedua ini 
dibandingan dengan siklus pertama. Ternyata masalah-masalah yang ada semakin berkurang dan dianggap tidak terlalu berarti, sehingga pelaksanaan model pembelajaran think pair share semakin baik dan lancar serta siswa lebih semangat dalam mengikuti kegiatan belajar. Sedangkan hasil kemampuan kognitif belajar Pendidikan Pancasila dan Kewarganegaraan (PPKn) materi perumusan dan penetapan Pancasila sebagai dasar negara melalui pelaksanaan model pembelajaran think pair share pada siklus II. Berdasarkan hasil observasi, dapat diketahui bahwa nilai rata-rata kemampuan kognitif dari 25 siswa adalah sebesar 81,48. Dari data tersebut, juga dapat diketahui bahwa jumlah siswa yang mendapatkan nilai KKM (kriteria ketuntasan minimal) sebanyak 22 siswa atau $88 \%$. Sedangkan yang mendapatkan nilai di bawah nilai KKM sebanyak 3 siswa atau $12 \%$. Pada siklus II ini terjadi peningkatkan berpikir yang cukup signifikan. Peningkatkan kemampuan kognitif, salah satunya adalah dipengaruhi oleh terbiasanya siswa mengadakan diskusi dalam kelompoknya, sehingga siswa yang belum paham mengenai materi pembelajaran tidak malu untuk bertanya pada temannya yang lebih menguasai tentang konsep tersebut.

Upaya meningkatkan pemahaman dan penguasaan serta bimbingan guru dalam melaksanakan model pembelajaran think pair share menunjukkan hasil yang memuskan. Hal ini terbukti dari kemampuan kognitif dan aktivitas belajar siswa dalam proses pembelajaran Pendidikan Pancasila dan Kewarganegaraan (PPKn) materi perumusan dan penetapan Pancasila sebagai dasar negara dapat meningkat.

Untuk merealisasikan usaha tersebut penelitian dilakukan melalui dua siklus yang terdiri dari empat komponen, yaitu: perencanaan tindakan, pelaksanaan tindakan, observasi, dan refleksi. Setiap pelaksanaan tindakan peneliti melakukan berbagai langkah sesuai dengan rencana perbaikan pembelajaran. Berikut pembahasan dari setiap pelaksanaan tindakan masing-masing siklus.

Pada tindakan I, guru melakukan tes awal (pre test) sebagai tolak ukur kemampuan individu siswa dan untuk mengetahui kesiapan belajar siswa terhadap materi yang akan dipelajari, serta melakukan perbaikan pembelajaran dengan menerapkan model pembelajaran think pair share. Adapun hasil kemampuan kognitif Pendidikan Pancasila dan Kewarganegaraan (PPKn) materi perumusan dan penetapan Pancasila sebagai dasar negara pada siklus I diperoleh data dapat diketahui bahwa nilai rata-rata kemampuan kognitif dari 25 siswa adalah sebesar 76,92. Jumlah siswa yang mendapatkan nilai KKM (kriteria ketuntasan minimal) sebanyak 18 siswa atau $72 \%$. Sedangkan yang mendapatkan nilai di bawah nilai KKM sebanyak 7 siswa atau $28 \%$.

Pada tindakan II, guru berupaya mengaktifikan siswa dalam proses pembelajaran dengan membimbing siswa melaksanakan model pembelajaran think pair share. Hal ini dilakukan dengan tujuan agar siswa dapat terlibat secara aktif untuk menemukan sendiri pengetahuan tentang konsep perumusan dan penetapan Pancasila sebagai dasar negara. Selain itu, siswa juga dituntut untuk dapat menyampaikan materi perumusan dan penetapan Pancasila sebagai dasar negara pada teman-temannya sekelas. Pada siklus II ini diketahui bahwa nilai rata-rata kemampuan kognitif dari 25 siswa adalah sebesar 81,48. Jumlah siswa yang mendapatkan nilai KKM (kriteria ketuntasan minimal) sebanyak 22 siswa atau $88 \%$. Sedangkan yang mendapatkan nilai di bawah nilai KKM sebanyak 3 siswa atau $12 \%$.

Berdasarkan nilai rata-rata kemampuan kognitif siklus I adalah sebesar 76,92 kemudian mengalami peningkatan pada siklus II adalah sebesar 81,48 . Sehingga terdapat peningkatan nilai kemampuan kognitif sebesar 4,56. 
Ternyata hasil evaluasi menunjukkan perbaikan yang cukup signifikan. Dengan demikian proses perbaikan pembelajaran yang dilakukan peneliti dapat terlaksana sesuai dengan tujuan perbaikan, sehingga kemampuan kognitif siswa dapat meningkat melalui penerapan model pembelajaran think pair share.

Sedangkan terkait pelaksanaan model pembelajaran think pair share pada materi perumusan dan penetapan Pancasila sebagai dasar negara, siklus pertama mengalami kesulitan karena siswa tidak terbiasa menggunakannya. Dengan bimbingan, arahan dan petunjuk guru, maka pelaksanaan model pembelajaran think pair share pada siklus kedua dapat dilakukan dengan baik dan lancar.

Berdasarkan hasil kemampuan kognitif Pendidikan Pancasila dan Kewarganegaraan (PPKn) materi perumusan dan penetapan Pancasila sebagai dasar negara dengan melaksanakan model pembelajaran think pair share yang diperoleh SMP Muhammadiyah Buntok mulai siklus I sampai dengan siklus II terus mengalami peningkatan yang cukup signifikan. Dengan demikian dapat dikatakan bahwa pelaksanaan model pembelajaran think pair share dapat meningkatkan kemampuan kognitif Pendidikan Pancasila dan Kewarganegaraan (PPKn) materi perumusan dan penetapan Pancasila sebagai dasar negara.

\section{KESIMPULAN}

Berdasarkan kesimpulan penelitian tersebut ialah :

1. Pelaksanaan model pembelajaran think pair share pada mata pelajaran Pendidikan Pancasila dan Kewarganegaraan (PPKn) materi perumusan dan penetapan Pancasila sebagai dasar negara SMP Muhammadiyah Buntok, siklus pertama mengalami kesulitan karena siswa tidak terbiasa menggunakannya. Dengan bimbingan, arahan dan petunjuk guru, maka pelaksanaan model pembelajaran think pair share pada siklus kedua dapat dilakukan dengan baik dan lancar.

2. Kemampuan kognitif Pendidikan Pancasila dan Kewarganegaraan (PPKn) materi perumusan dan penetapan Pancasila sebagai dasar negara yang diperoleh siswa SMP Muhammadiyah Buntok, sebelum dilaksanakan tindakan adalah kategori buruk. Kemudian setelah diberikan tindakan pertama meningkat menjadi kategori cukup, dan setelah diberikan tindakan kedua menjadi kategori baik.

3. Berdasarkan hasil penelitian, dapat diketahui kemampuan kognitif Pendidikan Pancasila dan Kewarganegaraan (PPKn) materi perumusan dan penetapan Pancasila sebagai dasar negara yang diperoleh siswa SMP Muhammadiyah Buntok dengan melaksanakan model pembelajaran think pair share mulai siklus I sampai dengan siklus II terus mengalami peningkatan yang cukup signifikan, yaitu dari kenaikan nilai rata-rata kemampuan kognitif sebesar 76,92 kemudian mengalami peningkatan pada siklus II adalah sebesar 81,48. Sehingga terdapat peningkatan nilai kemampuan kognitif sebesar 4,56. Dengan demikian kemampuan kognitif Pendidikan Pancasila dan Kewarganegaraan (PPKn) materi perumusan dan penetapan Pancasila sebagai dasar negara yang diperoleh siswa SMP Muhammadiyah Buntok mengalami peningkatan yang cukup signifikan setelah dilaksanakan model pembelajaran think pair share.

\section{DAFTAR PUSTAKA}

Afandi, Muhammad. (2011) Cara Efektif Menulis Karya Ilmiah Seting Penelitian Tindakan Kelas Pendidikan Dasar dan Umum, Alfabeta, Bandung.

Arikunto, Suharsimi. (2006) Prosedur Penelitian suatu Pendekatan Praktik, Rineka Cipta, Jakarta. 
Arikunto, Suharsimi., Suhardjono, dan Supardi. (2007) Penelitian Tindakan Kelas, Bumi Aksara, Jakarta.

Hadi, Sutrisno (2004) Metodologi Research 1, Andi Offset, Yogyakarta.

Kartono, Kartini. (1980) Pengantar Metodologi Research Sosial, Alumni, Bandung.

Mardalis, (2006) Metode Penelitian suatu Pendekatan Proposal, Bumi Aksara, Jakarta.

Nurhadi. (2004) Pembelajaran Kontekstual dan Penerapannya dalam KBK, Universitas Negeri Malang, Malang.

Riadin, Agung dan Ade Salahuddin Permadi. 2019. Implementasi Pembelajaran PKn untuk Membentuk Pribadi yang Berkarakter di SD Muhammadiyah Sampit. Pedagogik: Jurnal Pendidikan. 14:1(18-28).

Sagala, Syaiful. (2007) Konsep dan Makna Pembelajaran, Alfabeta, Bandung.

Saputra, Lukman Surya. (2017). Pendidikan Pancasila dan Kewarganegaraan (PPKn) untuk SMP/MTS. Kelas VII, Kementerian Pendidikan dan Kebudayaan, Jakarta.

Setiawan, Muhammad Andi dan Diplan. 2018. Penelitian Tindakan Kelas Teori Serta Panduan Bagi Guru Kelas dan Guru Bimbingan Konseling. Deepublish, 1:67.

Uno, Hamzah B. (2006) Perencanaan Pembelajaran, Bumi Aksara, Jakarta. 